\title{
THE POLITICAL ECONOMY OF DEMOCRACY IN TANZANIA*
}

\author{
Ernest T Mallya
}

\author{
Ernest T Mallya is in the Department of Political Science and \\ Public Administration, University of Dar es Salaam \\ P O Box Ubungo, Dar es Salaam, Tanzania \\ Tel: +255 22 2410357; Cell: +255 075 4306207; Fax: +255 222410084 \\ e-mail: emallya@hotmail.com
}

\begin{abstract}
Tanzania is one of the poorest countries in the world and, as is the case with other poor countries, there have been, for the past 20 years, internal and external efforts to try to free the country from the woes of poverty. There are many theories about what went wrong in Tanzania. These range from colonial domination - and its attendant problems of dependency and underdevelopment - to those which target capitalism and its 'predatory' nature, leading, among other things, to unequal exchange on the world market, world division of labour, and so on (Ellis 1983; Dutkiewicz \& Williams 1987) as well as the ubiquitous globalisation which currently affects many aspects of life. However, not everyone believes that these theories provide a plausible explanation for what happened and why. Some see the problem as structural and also cite the inappropriate policies pursued by many poor countries, which were candidly acknowledged by the Organisation of African Unity (1986, p 17). Others (eg, Babu 1991, pp 31-4, Shivji 1974, pp 85-90) blame the way the policy was implemented. We will examine the causes of the predicament more closely and demonstrate how things are changing.
\end{abstract}

\section{TANZANIA: A BRIEF PROFILE}

At the time of the 2002 census the population of Tanzania was 34 million, about 24 per cent of whom lived in urban areas. It is widely held that 50 per cent of Tanzanians live below a locally defined poverty line while 36 per cent live in

This paper was originally published in Italian $\square$ under the title 'anzania: l'economia politica della democratizzazione' in $\square$ Ariche e Orienti ol 8(3-4), 2006, pp 58-70. 
abject poverty (DFID 1999, p 1; URT 1999, p 7; Assey 1999, p 129). Studies indicate that poverty is likely to persist for the foreseeable future. Per capita income is about US $\$ 300$. Population growth is at 2,9 per cent, while the economy has been growing at about 6 per cent in the past four to five years. Of the rural population, which accounts for about 75 per cent of the total population, about 60 per cent live below the poverty line. In comparison, only 39 per cent of the urban population outside Dar es Salaam live below the poverty line.

Women, who comprise 51 per cent of the population, constitute 54 per cent of the economically active. However, women - and especially rural women bear the brunt of poverty. Of the economically active rural women, 98 per cent are engaged in agriculture, producing between 60 and 80 per cent of all domestic food supplies (URT 1998, p 5). They also contribute substantially to cash-crop production. Despite this, they are severally disadvantaged (Assey 1999, pp 1357; DFID 1999, p 2). Firstly, they do not have the same opportunities as men to access education. Secondly, there are outdated traditions that work against them. Thirdly, while they carry a heavy burden of production and reproduction in rural areas, their access to wage employment is very limited. Fourthly, they are underrepresented in decision-making bodies like Parliament, Cabinet and different committees, although efforts are under way to rectify this. For instance, since 2005 women's representation in Parliament through both constituency and special seats has been 30 per cent. Finally, many of them are ignorant of their rights.

\section{THE CONSOLIDATION OF PARTY POWER}

When African countries began to gain their political independence the state was seen and used as the main development agency. This was partly because dominant theories of the time advocated the centrality of the state in the development process. Moreover, during the struggles for independence nationalist leaders promised a range of economic and social changes which, given the circumstances, could only be achieved through the agency of the state. In most countries there were no indigenous entrepreneurs with enough capital to take on the challenges that came with independence. The state, therefore, for a considerable period, became an engine for development and the provider of goods and services. In this framework of provision in the newly independent states, political leaders became patrons, creating the networks of patron-client which are characteristic of African politics and which, to a large extent, have led to the characterisation of the African state as 'patrimonial' (Sandbrook, 1993).

To achieve the centrality of the state in the development process, policymaking in Tanzania was gradually designed to take a top-down approach. Few 
people (those who made the central committee - CC - of the only party) were the policy makers. Deliberate efforts were made by the ruling elite to exclude citizens from the policy process by concentrating policy-making power in the hands of fewer and fewer people. This is attested by the ruling elite's move to shift policy-making power from the Parliament to the party's national executive committee (NEC), where the CC became the ultimate policy-maker.

The exclusion of citizens from the policy-making process took place on two fronts. Firstly, civic organisations and ideas that did not conform to 'party ideals' were suppressed. Secondly, national public-policy-making bodies were subordinated to party organs. Consequently, citizens lacked autonomous avenues for participation. The adoption of a single-party constitution and the creation of the party as the supreme organ of the state elevated party organs to national policy-making level. The Cabinet, which should have been at the centre of the policy-making model, as it is in the inherited Westminster model, was deprived of its power over policy-making and replaced by the CC. Parliament became a committee of the party, subordinated to the party's NEC. What should be noted here is that these structural changes placed policy-making power in party organs, thereby giving the party chairman, who was also the president, enormous powers (Mushi 1981). The dual structure gave the president a great deal of discretion to decide which organ deliberated any particular policy.

\section{THE AUTHORITARIAN DEVELOPMENTAL STATE AND EXCLUSION}

The consolidation and institutionalisation of the state and party supremacy was carried out under the banner of 'nation-building', thereby justifying the exclusion of citizens from policy-making (Holmquist 1983). These processes led to the suppression of civil organisations and their forcible affiliation to the regime. It would seem that the state was suspicious of factionalism and sectarianism, and particularly, organised disagreement, which might lay the foundation for the formation of strong civic organisations.

Civic organisations which were permitted to operate were required either to be apolitical or pro-party. As a result, there was little, if any, room left for structuring autonomous civic organisations that could provide channels for citizens to participate in the policy process (Goulbourne 1980; Rodney 1980; Miti 1987). By the time the Arusha Declaration was announced in 1967, ushering in the policy of ujamaa (African socialism), the party had monopolised the organisation of society in most spheres of life and potential pressure groups such as women, youths, students, workers, and so on, had been co-opted.

In these circumstances, the policy process became highly exclusive and secretive. All possible avenues for policy expression outside the party were 
eliminated, undercutting not only policy critics but also citizens' initiatives and participation in policy-making. The ownership, censorship and monopoly of policy information by the state and its control over mass media worsened the situation. Most citizens were uninformed or ill informed and those who were informed lacked avenues for expression and participation in the policy process.

\section{THE STATE UNDER FIRE}

Like many other African countries Tanzania became a major recipient of aid after independence. Aid was needed by the new states to help them attend to the many demands placed on them as 'nationalist governments'. However, aid did not work as expected, a situation which has led to so-called 'donor fatigue' (see for example, Plank 1993) the perception of Africa as a 'bottomless pit'. Despite the quantity of resources directed to poor countries as a means of checking the appalling poverty in which many people lived, there were no tangible successes, and donors and development theorists began to ask questions and look for explanations, bringing the role of the state under scrutiny and resulting in the state being held responsible for the mess. The onslaught on the state as the prime cause of the problems was led by the international financial institutions - the World Bank and the International Monetary Fund (IMF) - whose help was necessary for the revival of the economies of these countries. Later, the donor community as a whole applied coordinated pressure on aid recipients to agree to the prescriptions of the two institutions.

It was realised that one of the results of reliance on the state to solve development problems in Africa has been the sidelining of civil society and the private sector as players in the entire development agenda. Even where some economic development was achieved the state-centric approach to development had another weakness - the conception of the state as a vehicle for economic prosperity and the solution of problems of development.

Economic development does not automatically lead to human development. Per capita income, for example, is, to say the least, a misleading indication of the economic welfare of the population of a country (Handy 1995, p 221). The failure of the state to bring about development led to a search for other solutions. This is where the role of society and the private sector in the whole matrix began to take centre stage in policy as well as academic fora (see for example, Hyden 1992). The weaknesses of the state - particularly in its relationship with civil society in the whole process of societal management - came to the fore. The general conclusion was that there is a need for civil society to participate in the political processes that shape the social and economic status of a country; that appropriate interaction between state, the private sector and civil society was a possible solution to the problems African countries were facing. 
It has been observed that the interests of state and society sometime merge and sometimes conflict (Nordlinger 1987). As Bratton \& Rothschild (1992, p 264) observe, struggles between the two are always damaging. In the case of Africa it was concluded that the state had been more involved than it should or could have been; that the private sector was not given enough chance; and that civil society was virtually, if not entirely, sidelined. There was a need to balance the relations between these three sectors.

\section{ECONOMIC AND POLITICAL LIBERALISATION}

With the economy in the doldrums by the early 1980s the government of Tanzania held talks with the financial institutions, especially the IMF, and improvised recovery programmes such as the National Economic Survival Programme (NESP) of 1981 / 1982 as well as the home-grown Structural Adjustment Programme (SAP) of 1982 (Stein 1990, pp 8-9). These efforts were aimed at attracting more resources for the state, but they were not successful. The state wanted to mobilise more resources for its use, but, at the same time, it maintained its traditional controlcum-exclusionist stance. Concentration of power remained in place. Meanwhile, the financial institutions and other donors were pushing for both economic and political liberalisation. The government began to liberalise the economy in 1986 when the IMF agreed to a loan of SDR 64,2-million contingent upon the achievement of certain agreed performance benchmarks according to timeframes agreed by both parties. This was to be named the Economic Recovery Programme (ERP I).

There were several conditions, however, which the government initially resisted but ultimately agreed to. These included devaluation, liberalisation of crop marketing, liberalisation of export and import trade, and the removal of subsidies to peasant farmers. More reforms were to follow in the late 1980s and early 1990s. They included:

- 'rolling back' the state, in line with the World Bank's paradigm shift in the mid-1980s (see, for example, World Bank Report 1981 - 'the Berg Report');

- the termination of free services and the introduction of user fees in some social services;

- the creation of executive agencies and freezing of wages in the public sector;

- the retrenchment of public sector workers in an attempt to control the wage bill, and several other measures, including the consolidation of allowances / fringe benefits in salaries so they are also taxed and 
the sale of government vehicles to the officers using them so that they bear the cost of maintaining them;

- restructuring and refining the parastatal sector - a large subsidy consumer.

In short, from 1986 all aspects of the Tanzanian economy began to wear a capitalist face.

After the economic liberalisation came political liberalisation, in 1992. Again this was the result of several factors, including the 'wind of change' in Eastern Europe that began in the late 1980s, internal pressure from activists and nongovernmental organisations (NGOs), pressure from donors and, according to Kiondo (1990, p 39), influence from within the only political party in which some members were pro-reform. After 27 years as a one-party state, the law was changed to allow the participation of other parties in the political system.

Hand in hand with that move, by this time NGOs and other civil society organisations were acting more freely than they had been. Organisations focusing on economic matters proliferated with the liberalisation of the economy. In 1993 some 11 new political parties were granted full registration. Others followed in subsequent years. Competitive politics within a multiparty framework was back in Tanzania. The first elections were the local government elections in 1993/94. The performance of the new parties was not impressive, but at least different opinions and a choice of candidates was now possible.

\section{ENTER ‘GOOD GOVERNANCE’: THE RIGHT POLITICS FOR DEVELOPMENT}

The Tanzania Development Vision 2025 (URT 1995) states that Tanzania 'cherishes good governance' and the rule of law in the process of creating wealth and sharing benefits, as well as empowering people so they can hold leaders and public servants accountable. The problem of where to locate the new relationship between the state, civil society organisations and the private sector gave rise to the concept of 'governance'.

Governance is not an entirely new concept, but it was given a particular meaning in the context of the juxtaposition of politics and development in African states. Sometimes the qualifier 'good' is prefixed. The term gained currency in the mid1980s when, for example, Dunn (1986) looked at good governance in terms of organisational effectiveness, with no particular emphasis on the philosophical orientation of the management of the state. The definitions of governance vary with the sources, but all, in some way, touch on certain key elements. The United Nations Development Programme (UNDP) (1997, p xi), for example, sees governance as: 
... the exercise of political, economic and administrative authority to manage the nation's affairs. It is the complex mechanisms, processes, relationships and institutions through which citizens and groups articulate their interests, exercise their rights and mediate their differences.

Hyden (1992, pp 7-8) defines good governance as the conscious management of regime structures aimed at enhancing the legitimacy of the public realm. The World Bank (1989), for its part, is in favour of good governance because it believes it will ensure the presence of human rights, check corruption, and promote democratisation as well as accountability. The Global Coalition for Africa considers the following to be elements of good governance:

- constitutional arrangements and human rights;

- primacy of legality and predictability of the law;

- responsible and transparent government;

- coherence of administrative institutions;

- openness and tolerance in the political system;

- participation by stakeholders;

- favourable climate for the private sector.

\section{The Components of Governance}

The concept and practice of governance encompass the processes and structures of society which guide political and socio-economic relationships while protecting people's values, beliefs, freedoms and security as well as guaranteeing the exercise of personal capacities that lead to a better life for the entire community.

Let us briefly discuss the three players in the new management of societal affairs under the governance framework:

- The state facilitates the presence of policy-making and implementation processes under a legitimate (state) authority. Expectations of this player include the presence of a stable political system, in particular a credible constitution which is acceptable to the majority and through which all the processes are regulated, making predictability possible. Such a constitution would provide for the democratic rights of the population, including provisions for human rights and freedoms, electoral processes, accountability mechanisms, allocation of powers to the agreed arms of government, and so on. The state should also provide an administrative system that 
faciliatates efficient policy implementation. This would include the presence of an efficient, independent, accountable and open public sector.

- Civil society organisations provide checks and balances on government power and on the private sector, but they can also contribute to strengthening both. Examples would include the help they can give in monitoring the environment, checking social and political abuse, running economic activities. When it comes to participation, civil society organisations become the training grounds for their members in the first place and, at a higher level, that is, in state politics, and so on, members become more confident and participate with greater efficiency and effectiveness. They speak for the vulnerable and the poor in society. In some cases (particularly those of cooperatives) they are able to help people overcome market failures and weaknesses.

- The private sector has assumed a greater role in the economies of developing countries in the recent past. With the state's ability to provide (often free) services to the population dwindling with time, the private sector - which, in many countries had long been suppressed - was considered the alternative-cum-partner in the provision of goods and services. Hand in hand with the arrival on the scene of the private sector is the reduction of state activity in the economy.

- This means, among other things, that there will be rationalisation, which usually comes with a cost in job losses.

- The private sector also brings improved technology, which, again, has its cost in job losses.

- On the other hand, production improves, tax revenues increase, and market distortions are eliminated.

- The state will have new challenges:

- As the economy is opened up, competition becomes stiffer. Local enterprises and businesses will need support in order to become competitive on world markets.

- On the local scene there will be a need to support formal and informal sector small businesses and enterprises by, for example, creating credit facilities. These are the sectors that will create jobs.

- There will always be the need to take care of casualties of the reforms - the unemployed and unemployable, the untrained and those who fit nowhere, and so on. 
- The state will have to monitor the relationship between the private sector and the environment. In many cases, the private sector has been found guilty of environmental degradation. The sustenance of the environment has become a necessary item on the agenda of good governance.

To sum up, it is obvious that the state, the private sector and civil society must cooperate if sustainable development is to be achieved. The claim of any of these to be able single-handedly to lead society to desired levels of development would be, as it has, until now, proven to be, an unrealisable objective. The state is required to safeguard law and order as well as to provide the required massive investments in infrastructure. The state must also provide the legal framework in which competing entrepreneurs and other members of society will operate. The private sector's innovation and ingenuity is required to alleviate the problems of joblessness, failures associated with the state, archaic technology and business techniques, poor quality goods, and so on.

\section{WINNERS AND LOSERS: \\ LEGITIMACY, POLITICS AND ECONOMICS}

Legitimacy is a distinct form of political support that concerns evaluations of the state from a public or 'common good' perspective (Easton 1965, pp 278, 312). Gilley (2006, p 48) locates where and when a state can earn its legitimacy by saying that 'a state is more legitimate the more it is treated by its citizens as rightfully holding and exercising political power'. Among the factors that give legitimacy to a regime are, according to him, good governance, democratic rights and welfare gains.

These may not be compatible bedfellows when it comes to a newly independent country. Independence governments needed to consolidate power by different means in order to be able, at least partially, to deliver what they promised during the fight for independence and partially to pander to the interests of the emerging elites. This would guarantee them the required legitimacy.

The result was that only welfare gains counted - democracy and good governance were not priority issues at the time. In this respect Tanzania was no different from many other new African governments. This is why some (for example, Kiondo 1990) describe the state in Tanzania as authoritarian, with economic and political control over civil society. The result was that when the economy was in trouble extra economic coercion was applied in order to appease the emerging elites while, at the same time, forcing the disenchanted masses to 
go on producing - for local consumption and for export. The elite in this case was in the commercial sector as well as the bureaucratic bourgeoisie (Shivji 1990) and acted as a compradorial class for the former in its role of linking the state and international capital. This was the case when Julius Nyerere was in power.

After Nyerere resigned from active politics in 1985 economic liberalisation started in earnest. His successor, President Ali Hassan Mwinyi, had to carry out the economic reforms his predecessor had denied Tanzanians. In 1991 he and his colleagues in the party issued the Zanzibar Declaration, which opened the doors for political leaders to participate in business - something that was not allowed during the Arusha Declaration years. The remarkably little private capital there was began to increase through private capital accumulation and a 'nouveau riche' group of entrepreneurs joined the political and bureaucratic elites in the race for wealth accumulation. These reforms further threatened the interests of the former elite who already felt that the redistributive policies followed under Ujamaa had dealt them a blow, as resources were being directed to the lower and less privileged sections of the population (Shivji 1990).

Examined closely, the reforms associated with cutbacks in public expenditure point to a situation in which the poor will suffer most. Given the corruption levels that prevailed in Tanzania those in government office, even if they were not in high positions, could make use of user fees and charges for services that had previously been free as a bargaining chip to exchange for the money to cover the expenses that will be brought about by the reforms. The most unlucky were the peasants, who had no say in their produce prices and nothing to hold on to to mitigate the effects of the reforms. In such a situation the emerging commercial elites and the political and bureaucratic elites found a means to survive at the expense of the majority peasantry.

\section{The Lethal Alliances}

An alliance between politicians and businesspeople resulted in the emergence of a group of rich people who indulged in conspicuous spending while the peasants languished in poverty thanks to the neglect of the agricultural sector by the Mwinyi regime. With the emerging patterns of accumulation, businesspersons started to seek political office, especially vying for legislative seats, while at the same time politicians launched a silent campaign to accumulate wealth either by cooperating with business or through graft.

The levels of graft, and corruption in general, were high by 1995 when the third-phase government (under Mkapa) came to power. As a result, the government was not collecting taxes, the public service work ethic eroded and government services were under funded. This led to the erosion of the legitimacy 
of the government, a factor that was addressed by the Mkapa regime in 1996 through the Warioba Commission on corruption. The commission's findings and recommendations did not, however, affect the levels of corruption and little action was taken against corrupt officials because of the absence of hard evidence that could lead to successful prosecution.

At some point during the Mkapa regime lethal alliances were formed between the political, the economic and senior law enforcement elites in get-rich-quick ventures that turned into 'mafia-style' organisations. As noted above, politicians began to do business, business elites began to seek political office and law enforcement officers became trapped under the influence of the business elites into protecting both legal and illegal businesses. Graft was common in relation to public procurement contracts. During this time political clientelism intensified, more so when the ruling party - the Chama Cha Mapinduzi (CCM) realised that the opposition parties were not a real threat and it still controlled the politics but not the economy.

Big business openly supported the ruling party after it became disillusioned with the opposition parties after the 1995 elections. Although the control of the economy was ultimately in the hands of forces outside the government because of reforms and globalisation, the CCM was, indirectly, both powerful internal negotiator and kingmaker. In addition, the CCM controlled the government, which issued licences and permits to business. In some way, clientelism increased levels of corruption, as people sought favours rather than engaging in productive activities.

At the level of policy, the government tried to appease the population by making decisions about poverty reduction; the improvement of the education system, starting with primary education; and other programmes backed by the World Bank and bilateral donors. The gap between poor and nouveau riche was staggering. While some urban dwellers could afford only one meal a day, their compatriots were sending their children to study abroad, shopping abroad, getting medical treatment abroad, and constructing homes worth billions of shillings.

The unemployed youth, now exposed to Western life through the liberalisation of the media, and the conspicuous spending by a few Tanzanians created a prime breeding ground for criminals, especially with regard to the use of small arms in robberies and other violent crimes. Armaments were easy to obtain thanks to the conflict situation in the Great Lakes region which surrounds Tanzania and the almost daily influx of refugees into the country. While tax collection had improved tremendously during the Mkapa regime, this was not reflected in people's lives. One reason for this was the fact that the regime was focusing more on building the macro aspects of the economy, including infrastructure, so people could market their produce. 
The legitimacy of the third-phase government was based on rhetoric and perhaps some success in putting macro-economic structures in place, promoting good governance, facilitating the democratisation process and fighting corruption. There has also been a strategy for the reduction of poverty, part of which involves channelling funds to villages and district councils, allowing people to plan and implement their development projects. However, when the current government began to act on issues like graft and the collusion between law enforcers and the criminal fraternity, the inertia that abounded in the public service, and the misuse and embezzlement of funds intended for local development, some began to question that legitimacy. Perhaps what needs to be said here is that legitimacy is also relative to the performance of other African governments. Tanzania has been praised thus far, despite some weaknesses in its political and economic structures and despite slippages that expose discrepancies between government policy and reality.

A general election was held in 2005 and during the first months in office of the newly elected government some of the alliances began to crack. The alliance between law enforcement agencies and the business community came under scrutiny. The police force was used by the business elites to protect illegal and legal businesses vis-à-vis the state (taxes), and also against the man in the street (compromised security). There was concern about the fact that some top police officers were part of this criminal world. On the other hand, it came to light that some political elites were engaged in graft through contracts signed during the third phase and beyond, for instance, in the mining, tourism, natural resources and energy sectors. Some of these contracts will now be reviewed.

\section{CONCLUSION}

The situation in Tanzania is the logical outcome of uncontrolled interaction between the political, bureaucratic and business elites. With the removal of the restrictions placed on politicians by the Arusha Declaration and by the Zanzibar Declaration of 1991 political elites started to do business and business elites became interested in politics with the two combining and complementing each other through reciprocal favours which put them in pole position to reap economic benefits. Since political elites require the support and actions of the bureaucratic elites to enable them to operate through government machinery it was no wonder that the latter had to be brought into the fold. In a situation where graft is common, the two must collude to make things work for them. And, where there is graft in government, the business elites are the likely suppliers of goods, giving out money in order to win contracts.

Politicians must use the bureaucracy to implement their devious plans. So the trio-business, political and bureaucratic elites - formed a web of actors through 
which the allocation of public resources was skewed, so the legitimacy of the governments of Mwinyi and Mkapa was never either permanent or stable, it depended on 'bold' action being taken by the government at a particular time. Where does this leave Tanzania's democracy?

It would be correct, we believe, to talk of a situation in which the people are facing a 'democratic deficit' (ADB 2000), that is, a situation in which democracy is confined - at least at the local level - to franchise issues and electoral participation rather than expanding into the wider context in which the people participate in decision-making. The benefits people have expected from the multiparty political arrangements - such as a more robust Parliament, betterdebated policies and more inclusion - are yet to materialise. Parliament has remained one-party dominated and, therefore, controlled. The same party also controls most of the local councils. In other words, the minorities (in terms of party affiliation) are yet to have a forum in which their ideas and preferences can be heard and acted upon.

Although the basic structure of a more democratic Tanzania is slowly being put in place by means of piecemeal constitutional changes, there is a need to develop a better performing economy to enable the economic (welfare) benefits to reach a wider community than they do currently. Since democracy consists of more than the franchise, if the current government is to maintain or increase its legitimacy it must address 'social welfare' issues, as proposed by Gilley (2006), in addition to those of good governance and democracy. This is all the more necessary because of the gradual emergence of classes in Tanzanian society. Without that attention the benefits of democratisation and good governance will be an illusion for the majority of Tanzanians.

\section{— REFERENCES}

Asian Development Bank [ADB]. 2000. To Serve and to Preserve. New Delhi: ADB. Assey, P B. 1999. 'Poverty Alleviation Initiatives in Tanzania'. In V S Vyas \& P Bhargava (eds). Poverty Reduction in Developing Countries: Experiences from Asia and Africa. New Delhi: Rawat Publications.

Babu, M A. 1991. 'A New Europe: Consequences for Tanzania'. Review of African Political Economy 50.

Bratton, M \& D Rothschild. 1992. 'The Institutional Bases of Governance in Africa'.

In M Bratton \& G Hyden (eds). Governance and Politics in Africa. Boulder: Lynne Rienner.

Department For International Development (DFID, UK). 1999. Tanzania: Country Strategy Paper. DFID, East Africa. 
Dunn, J. 1986. 'The Politics of Representation and Good Government in PostColonial Africa'. In P Chabal (ed). Political Domination in Africa: Reflections on Limits of Power. Cambridge: CUP.

Dutkiewicz, P \& G Williams. 1987. 'All the King's Horses and All the King's Men Couldn't Put Humpty-Dumpty Together Again'. IDS Bulletin 18(3).

Easton, D. 1965. A Systems Analysis of Political Life. Chicago, IL: University of Chicago Press.

Ellis, F. 1983. 'Agricultural Marketing and the Peasant-State Transfers in Tanzania'. Journal of Peasant Studies 10(4).

Gilley, B. 2006. 'Determinants of State Legitimacy: Results for 72 Countries'. International Political Science Review 27(1).

Goulbourne, U. 1980. 'Some Aspects of Ideological Functions in the Development of Post-Colonial State'. In H. Othman (ed). The State in Tanzania. Dar es Salaam: Dar es Salaam University Press.

Handy, C. 1995. The Empty Raincoat: Making Sense of the Future. London: Arrow Books.

Holmquist, F. 1983. 'Tanzania's Retreat from Statism in the Countryside'. Africa Today $4^{\text {th }}$ Quarter.

Hyden, G. 1992. 'Governance and the Study of Politics'. In G Hyden and M Bratton (eds). Governance and Politics in Africa. Boulder: Lynne Rienner.

Kiondo, A. 1990. 'The Nature of Economic Reforms in Tanzania'. Taamuli: A Political Science Forum 1(1\&2).

Miti, K. 1987. Whither Tanzania? New Delhi: Ajanta Publications.

Mushi, S S. 1981. 'The Making of Foreign Policy in Tanzania'. In S S Mushi and K Mathews (eds). Foreign Policy of Tanzania 1961-1981 - A Reader. Dar es Salaam: Tanzania Publishing House.

Nordlinger, E. 1987. Autonomy of the Democratic State. Cambridge: Harvard University Press.

Organisation of African Unity. 1986. Africa's Submission to the Special Session of the United Nations General Assembly on Africa's Economic and Social Crisis. Addis Ababa, March.

Plank, D N. 1993. 'Aid, Debt and End of Sovereignty: Mozambique and its Donors'. Journal of Modern African Studies 31(3).

Rodney, W. 1980. 'Class Contradiction in Tanzania'. In H. Othman (ed). The State in Tanzania. Dar es Salaam: Dar es Salaam University Press.

Samoff, J. 1992. 'Theory and Practice in the Analysis of Tanzania Liberalization: A Comment'. In H. Campbell \& H. Stein (eds). Tanzania and the IMF: The Dynamics of Liberalization. Boulder: Westview.

Sandbrook, R. 1993. The Politics of Africa's Economic Recovery. Cambridge: Cambridge University Press. 
Shivji, I. 1974. The Silent Class Struggle. Dar es Salaam: Tanzania Publishing House. - 1990. 'The Politics of Liberalization in Tanzania: Notes on the Crisis of Ideological Hegemony' Political Science Forum 1 (1 \& 2).

Stein, H. 1990. 'The Economics of the State and the IMF in Tanzania'. Taamuli: A Political Science Forum $1(1 \& 2)$.

UNDP. 1997. Re-conceptualizing Governance. Discussion Paper No 2. New York: UNDP. United Republic of Tanzania (URT). 1992. Political Parties Act, No 51992 (Dar es Salaam: Government Printer).

— 1995. The Tanzania Development Vision 2025. Dar es Salaam: President's Office, Planning Commission.

— 1998. The National Poverty Eradication Strategy. Dar es Salaam: Vice-President's Office.

-1999. Poverty and Welfare Monitoring Indicators. Dar es Salaam: Vice-President's Office.

World Bank. 1981. Accelerated Development in Sub-Saharan Africa: An Agenda for Action. Washington, DC: World Bank.

—. 1989. Sub Saharan Africa: From Growth to Sustainable Development. Washington, DC: World Bank. 